\title{
On the Roots of Bignonia.
}

\author{
BY \\ T. G. HILL, \\ National Scholar in Botany, Royal College of Science, London.

\section{With Plate XXII.}

$\mathrm{H}^{2}$

AVING had the opportunity of investigating the rootstructure of a few species of Bignonia, it seemed desirable, as there exist some doubts as to whether the roots of these plants follow the anomalous structure of the stem, to put the results obtained on record.

As far back as 1850 Crüger ${ }^{1}$ drew attention to the curious tuberous growths found on the roots of Bignonia Unguis, and he also stated that the same anomaly occurred in the roots as in the stem. This was subsequently denied by later investigators. Thus Bureau ${ }^{2}$ says, 'M. Crüger ... Il a suivi, dit-il, ce développement sur le Bignonia Unguis. J'ai $\mathrm{pu}$ examiner une racine de cette même espèce, et je dois dire que mes observations ne s'accordent point avec celles de M. Crüger.' Further on in his monograph he states: 'On ne voit point le tissu ligneux s'arrêter dans son développement sur quatre points opposés en croix, et le liber remplir les vides

1 H. Crüger, Bot. Ztg., Vol. viii, pp. I09-I Iо.

2 Bureau, Monogr. des Bignoniacées, I864, p. I 49.

[Annals of Botany, Vol. XII. No. XLVII. September 1898.] 
ainsi formés: mais il y a néanmoins une pénétration de l'écorce dans le bois.' It may, however, be stated that Bureau remarks that he had some doubts as to whether his plant was really Bignonia Unguis and not Stigmaphyllon; he decided it was the former, on account of the character of the sieve-tubes. Judging from further remarks which he makes on the root-structure of this plant, it is very probable that his material came from a wrongly named specimen. De Bary ${ }^{1}$ states that he was unable to find the characteristic stemstructures in the roots of Bignonia capreolata.

Van Tieghem ${ }^{2}$ states at the end of his description of the stems of these plants: 'Les racines de ces mêmes Bignoniacées ne paraissent pas présenter ces anomalies.'

Before passing on to the root-structure of these plants it will, perhaps, be well to briefly describe the structure which obtains in the stem for the sake of comparison,

Secondary thickening begins quite normally, as in other dicotyledonous woody plants. Sooner or later the development of secondary wood slackens very much at four points arranged cross-wise; and as the secondary growth of wood at the intermediate portions of the circumference continues at the same rate as before, it follows that four depressions are left dipping down into the secondary wood: but inasmuch as the formation of phloem at these four points is increased in inverse proportion to the decreased formation of wood, it is obvious that the depressions are quite filled up with phloem as far as the outer limits of the bast, so that the general external form of the stem remains similar to that of an ordinary plant. These four phloem-wedges are very characteristic of many Bignonias. The cambium at the bottom of each depression still slowly forms xylem-elements, and in the cortex of the stem numerous sclerenchymatous masses occur.

An essentially similar structure obtains in the root. In the ordinary root four phloem-wedges are found, and their development is identical with those of the stem.

1 De Bary, Comp. Anat., Eng. ed., p. 573.

2 Van Tieghem, Traité de Botanique, p. 823. 
We will now turn to a more detailed description of the root-structure in various species.

Bignonia Unguis. In this species the anomalous structure of the stem is undoubtedly present in the root. The structure of the normal root without any sunken phloem is illustrated by Fig. I, the protoxylem and the medullary rays are well marked and quite typical. With this illustration might be compared Fig. 2, which is a somewhat diagrammatic representation of a transverse section of an older part of the root figured in Fig. I. It will be observed that the formation of sunken phloem has gone on to some extent.

The first indication of the sunken phloem makes its appearance in quite small roots from .8 to $\mathrm{I} \mathrm{mm}$. in diameter, with five to ten cells in the radial rows of secondary wood. Such a stage is indicated in Fig. 3, which illustrates a transverse section of a young root. It will be seen that that protoxylem $(p x y)$ is well marked, and is typically that of a root both as regards structure and position; secondary growth of wood has not gone on to any great extent; the phloem exhibits very fine sieve-tubes and companion-cells; and finally the cortical sclerenchyma is made up of fibres lignified to a very great extent, so that the lumina are quite small. In these fibres very fine simple pits were to be seen in the preparation from which this figure was taken.

On the other hand, in some roots with about 26 cells in the radial rows of secondary wood the process has not gone much farther; thus it seems that the development of the sunken phloem does not originate at the same time in equally developed roots. In roots of about $\mathrm{I} \cdot 3 \mathrm{~mm}$. diameter the development has proceeded until, with a diameter of I. $76 \mathrm{~mm}$., the stage has reached that figured in Fig. 4 . In some roots of a smaller diameter than the last, viz. $1.5 \mathrm{~mm}$., the development has gone on to a greater extent, the sunken phloem being .28 to $.3 \mathrm{~mm}$. in depth (measured from the outer limit of the wood). Such a stage is indicated in Fig. 5 .

Crüger ${ }^{1}$ states that the anomaly is not so regular as in

1 Loc. cit. 
the stem. I have been unable to verify this. Most of my preparations show a very regular structure, e.g. those of the stage indicated in Fig. 5, and only in one case have indications of six phloem-wedges been seen.

The roots of Bignonia Unguis have a further interest in the fact that, at intervals, they swell out into tuberous growths resembling those occurring in the roots of certain species of Asparagus; they may attain a diameter of about $\mathrm{I} \mathrm{cm}$. and a length of about $\mathrm{J} \frac{1}{2} \mathrm{~cm}$.

In a transverse section it is seen that there are many points of similarity between the tuberous and the ordinary roots. For instance, there is a well-developed periderm, and in the cortex there are numerous masses of sclerenchymatous elements. In the tuberous roots, however, they are arranged more regularly in concentric rings, and the masses also grow smaller towards the periphery; the sieve-tubes and companion-cells are well marked; and finally there are wellmarked protoxylem-groups.

The chief points of dissimilarity between the tuberous and other parts of the root lie in the great development in the former of parenchyma in the cortex and, to a lesser extent, in the pith; and also in the breaking up of the xylem into separate masses, often by a certain amount of dilatation parenchyma.

There can be no question as to the structures described above belonging to the roots. In the first instance the material was carefully examined for any evidence of stemnature in the shape of buds, \&c., but without any success; then again the tuberous growths on the root are characteristic of the genus, the externally placed protoxylem is typically that of the root, and finally no phloem was found opposite the groups of protoxylem.

Bignonia venusta closely corresponds with Bigonia Unguis in the possession of sunken phloem in the roots. The first indications of the anomaly were found in roots of about $.97 \mathrm{~mm}$. in diameter : in other roots of about $1 \mathrm{~mm}$. diameter the phloem-wedges were about six cells in depth, while in 
roots of $1.4 \mathrm{~mm}$. in diameter the depth was about twice as great.

Bignonia capreolata is the only other species which has been examined; its roots do not show the anomalous structure of the stem; and although my material reached a diameter of $3 \mathrm{~mm}$. and the outline of the phloem was distinctly waved, still there were no indications of the formation of sunken phloem.

The general structure of the root resembles that of Bignonia Unguis, the chief differences being the great amount of cortical tissue, and the less abundant cortical sclerenchyma not grouped together in masses, but in many groups with a few fibres each, in this species. 


\title{
EXPLANATION OF FIGURES IN PLATE XXII.
}

\author{
Illustrating Mr. Hill's paper on Bignonia.
}

All the Figures refer to Bignonia Unguis.

Abbreviations : camb., cambium; c. c., companion-cells ; co., cortex; cr.ph., crushed phloem; $m . r$., medullary ray; ph., phloem; $p x y$., protoxylem; $p . w$. , wedge of sunken phloem; scl., sclerenchyma; $x y$., xylem.

Fig. I. Transverse section of a root.

Fig. 2. Transverse section of an older part of the same root as the last (somewhat diagrammatic).

Fig. 3. Similar section from another root.

Fig. 4. Transverse section of an older root showing an early stage in the development of the sunken phloem.

Fig. 5. Diagram of a transverse section of a root showing the sunken phloem well developed. 
Annals of Botany

Vol.XII, PI.XXII.

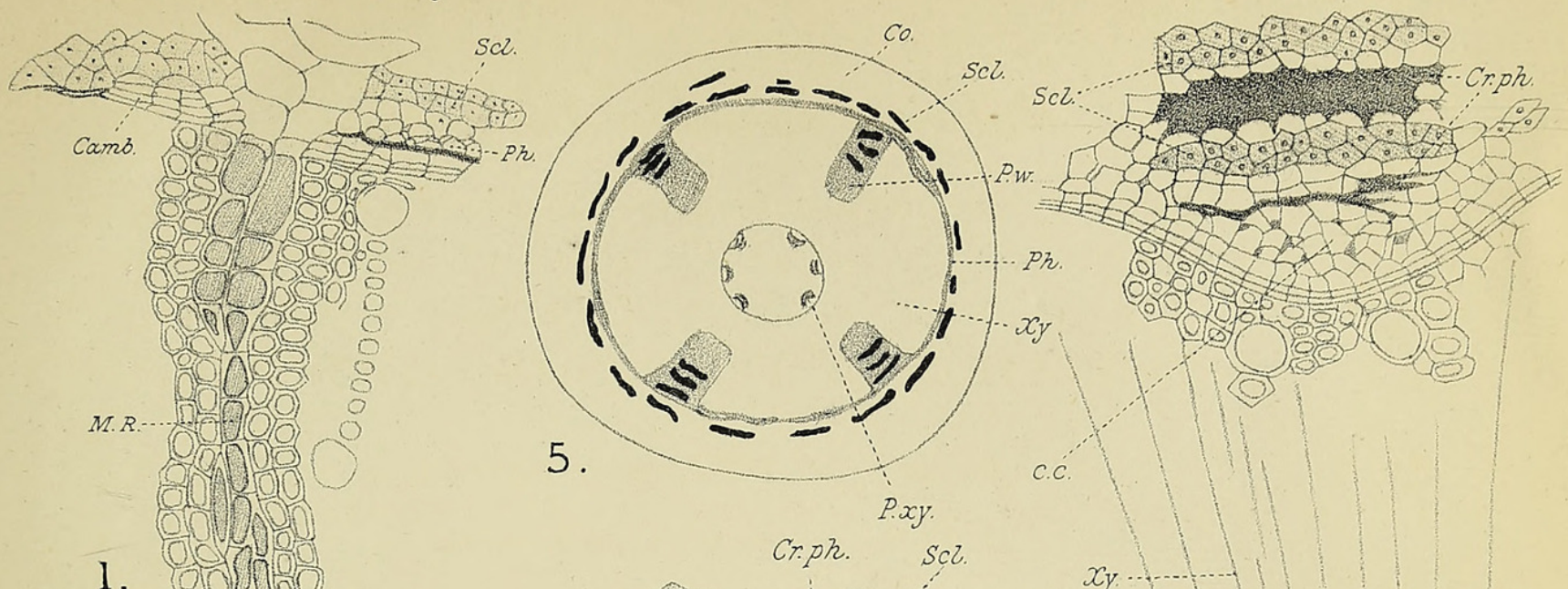

1

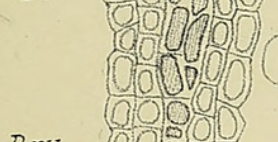

P.xy

0,00
0,00
001 500000

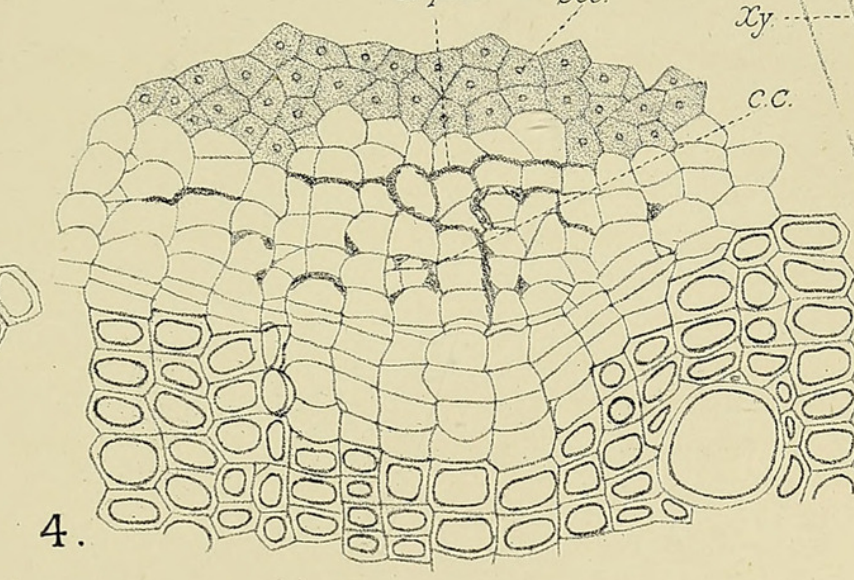

2. Pxy

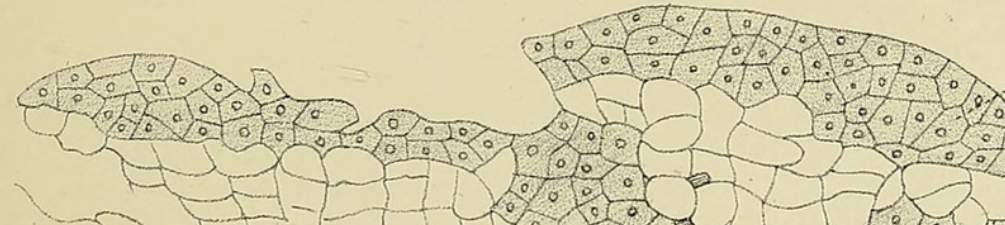

ScZ

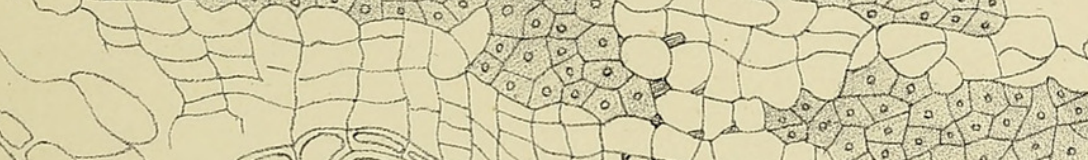

camb.
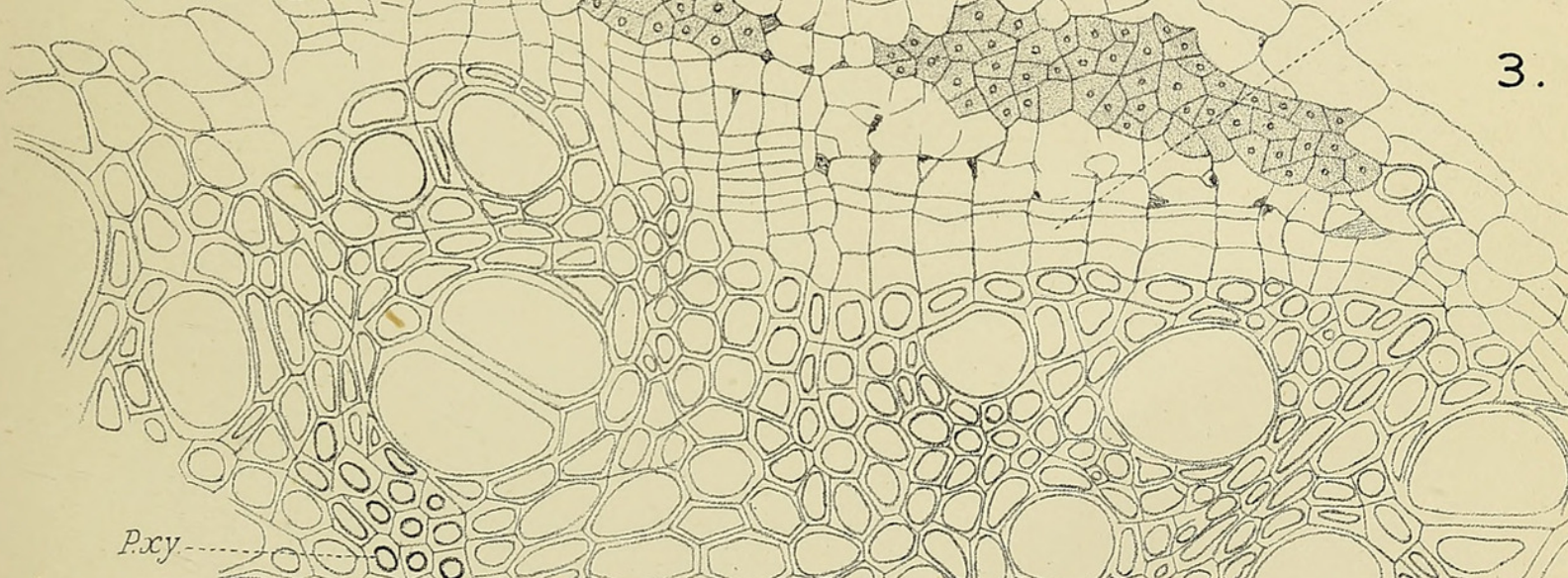

P.xy.

$5,500 \% 00$

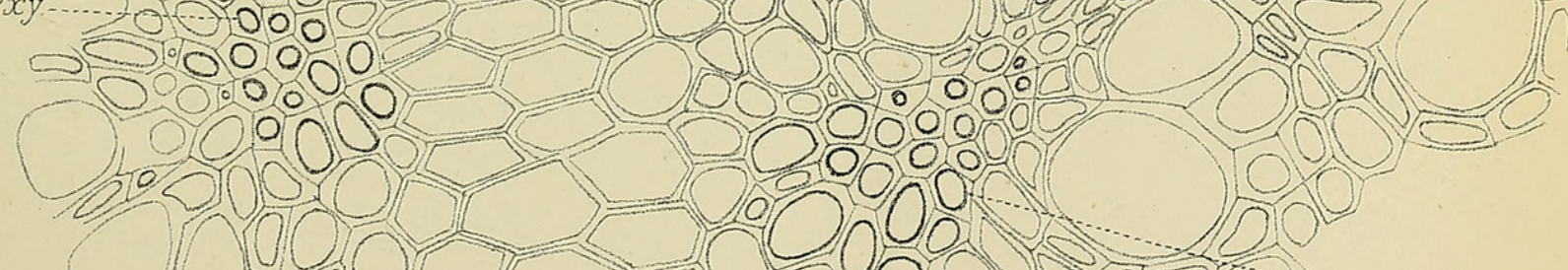

T. G.Hill del.

3.

P.xy.

HILL.- ROOT OF BIGNONIA. 


\section{$2 \mathrm{BHL}$ Biodiversity Heritage Library}

Hill, T. G. 1898. "On the roots of Bignonia." Annals of botany 12, 323-328. https://doi.org/10.1093/oxfordjournals.aob.a088697.

View This Item Online: https://www.biodiversitylibrary.org/item/233102

DOI: https://doi.org/10.1093/oxfordjournals.aob.a088697

Permalink: https://www.biodiversitylibrary.org/partpdf/318509

\section{Holding Institution}

Smithsonian Libraries

\section{Sponsored by}

Biodiversity Heritage Library

\section{Copyright \& Reuse}

Copyright Status: Not in copyright. The BHL knows of no copyright restrictions on this item.

This document was created from content at the Biodiversity Heritage Library, the world's largest open access digital library for biodiversity literature and archives. Visit BHL at https://www.biodiversitylibrary.org. 